\title{
Muscle fibre type changes in hypothyroid myopathy
}

\author{
R. O. McKeRAN 1, G. SLAVIN ${ }^{2}, T$. M. ANDREWS 1, P. WARD ${ }^{2}, A N D$ W. G. P. MAIR \\ From The Divisions of Inherited Metabolic Diseases ${ }^{1}$, and Cell Pathology ${ }^{2}$, Northwick Park Hospital and \\ Clinical Research Centre, Harron, and the National Hospital for Nervous Diseases ${ }^{3}$, Queen Square, London
}

SYNOPSIS Changes in muscle fibre type in hypothyroid myopathy were studied by serial percutaneous needle biopsy of vastus lateralis before and during treatment with L-thyroxine. A type II fibre atrophy and loss was found, which correlated with the clinical and biochemical evidence of a myopathy. The type II fibre atrophy was corrected by L-thyroxine but type II fibre loss was still apparent in severely myopathic patients up to two years after starting treatment. The pathogenesis and significance of type II fibre atrophy and loss are discussed in relation to prognosis.

More than $90 \%$ of patients with hypothyroidism have evidence of significant muscular involvement indicated by elevated serum creatine phosphokinase levels (CPK, adenosine $5^{\prime}$ triphosphate-creatine phosphotransferase, EC 2.7.3.2, Graig and Smith, 1965; Griffiths, 1965). Clinical evidence of myopathy occurs in $30-80 \%$ of patients (Nickel, Frame, Bebin, Tourtellotte, Parker, and Hughes, 1961; Ozker, Schumacher, and Nelson, 1960). The main features are weakness, cramps, aching or painful muscles, sluggish movements, myoedema, and occasionally an increase in muscle bulk. Treatment with L-thyroxine leads to complete clinical recovery within two to six months in most cases, but in some the recovery may be delayed or incomplete.

Few pathological studies of muscle in hypothyroidism have been reported and these based on paraffin sections have indicated only minor changes (Ramsay, 1974). The relatively atraumatic procedure of percutaneous needle biopsy permitted serial study of muscle fibre type changes in a wider spectrum of patients than would be justifiable with conventional open biopsy techniques.

\section{Patients and Methods}

Six hypothyroid patients were studied by serial percutaneous needle biopsies of vastus lateralis before and during treatment with L-thyroxine for up to 24 months to establish the diagnosis and response to therapy. The evidence for a myopathy ranged from elevation of serum CPK alone to gross wasting and weakness of proximal muscle groups. The main clinical and biochemical features of these patients are shown in table I, together with the Received for publication 6 February 1975. timing of the muscle biopsies in relation to the duration of treatment. Normal volunteers served as age and sex matched controls.

Using a modified Bergström needle $(3$ or $5 \mathrm{~mm}$ diameter) vastus lateralis was biopsied under local analgesia (5-8 $\mathrm{ml}$ of $1 \%$ lignocaine) through a $5 \mathrm{~mm}$ incision in the skin and deep fascia (Edwards, 1971). Specimens (30-60 mg wet weight) were allowed to relax in air at room temperature for 15 minutes, before snap freezing in isopentane cooled in liquid nitrogen. Cryostat sections were cut with the muscle orientated for cross sections, stained for myosinATPase pH 9.4 (Padykula and Herman, 1955; Hayashi and Freiman, 1966), and photographed. From the photographic prints ( $\times 250$ magnification) the proportion of type I to type II fibres was determined and the diameters of 200 fibres were measured as the maximum distance across the lesser aspect of the muscle fibre (Brooke and Engel, 1969a, b).

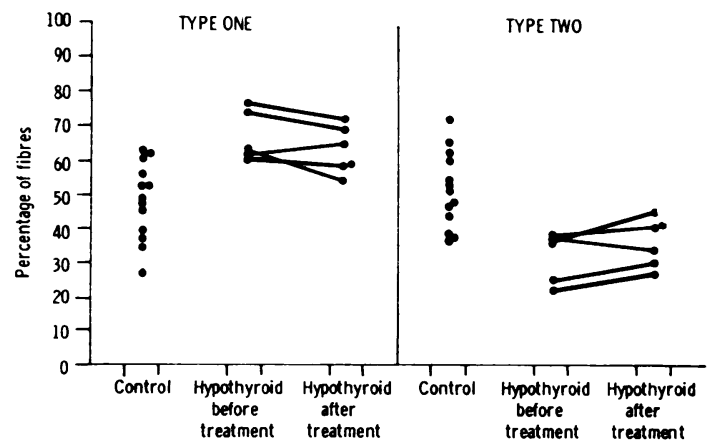

Fig 1 Percentage of type I and type II fibres from individual hypothyroid patients before and during treatment with $L$-thyroxine together with values for controls of comparable age and sex. 


\begin{tabular}{|c|c|c|c|c|c|c|c|c|c|c|}
\hline \multirow{2}{*}{$\begin{array}{l}\text { Patient } \\
\text { Number }\end{array}$} & \multirow{2}{*}{$\begin{array}{l}\text { Age } \\
\text { (years) }\end{array}$} & \multirow[t]{2}{*}{ Sex } & \multirow{2}{*}{$\begin{array}{l}\text { Clinical } \\
\text { Myopathy }\end{array}$} & \multirow{2}{*}{$\begin{array}{l}T S H \\
(\mu \mu / m l)\end{array}$} & \multirow{2}{*}{$\begin{array}{l}T_{3} \text { Uptake } \\
\% \text { normal } \\
(95-119)\end{array}$} & \multirow{2}{*}{$\begin{array}{l}T_{4} \\
(\mathrm{nmol} / \mathrm{l}) \\
(60-180)\end{array}$} & \multirow{2}{*}{$\begin{array}{l}C P K \\
(I U / l) \\
(5-80)\end{array}$} & \multirow{2}{*}{$\begin{array}{l}\text { Muscle Biopsy } \\
\text { (duration after } \\
\text { treatment) }\end{array}$} & \multicolumn{2}{|c|}{ Muscle Fibre Percentage } \\
\hline & & & & & & & & & Type I & Type II \\
\hline 1 & 62 & $\mathbf{M}$ & + & 160 & 145 & 5 & 847 & $\begin{array}{l}\text { Before treatment } \\
7 \text { months } \\
15 \text { months } \\
24 \text { months }\end{array}$ & $\begin{array}{l}77 \\
77 \cdot 5 \\
67 \\
72\end{array}$ & $\begin{array}{l}23 \\
22 \cdot 5 \\
33 \\
28\end{array}$ \\
\hline 2 & 64 & $\mathbf{M}$ & $\because$ & $155 \cdot 7$ & 130 & 3 & 1045 & $\begin{array}{l}\text { Before treatment } \\
4 \text { months }\end{array}$ & $\begin{array}{l}74 \cdot 5 \\
69\end{array}$ & $\begin{array}{l}25 \cdot 5 \\
31\end{array}$ \\
\hline 3 & 60 & $\mathbf{F}$ & - & $18 \cdot 5$ & 118 & 17 & 144 & $\begin{array}{l}\text { Before treatment } \\
9 \text { months }\end{array}$ & $\begin{array}{l}62 \\
65 \cdot 5\end{array}$ & $\begin{array}{l}38 \\
34 \cdot 5\end{array}$ \\
\hline 4 & 50 & $\mathbf{F}$ & - & $47 \cdot 7$ & 116 & 47 & 108 & $\begin{array}{l}\text { Before treatment } \\
7 \text { months }\end{array}$ & $\begin{array}{l}61 \\
58 \cdot 5\end{array}$ & $\begin{array}{l}39 \\
41 \cdot 5\end{array}$ \\
\hline 5 & 63 & $\mathrm{~F}$ & + & 50 & 112 & 57 & 523 & $\begin{array}{l}\text { Before treatment } \\
7 \text { months }\end{array}$ & $\begin{array}{l}63 \\
54\end{array}$ & $\begin{array}{l}37 \\
46\end{array}$ \\
\hline 6 & 39 & $\mathbf{F}$ & - & $20 \cdot 7$ & 97 & 56 & 60 & $\begin{array}{l}\text { Before treatment } \\
5 \text { months }\end{array}$ & $\begin{array}{l}\text { Unsatisfactory } \\
\text { for } \\
\text { measurement } \\
58.5\end{array}$ & $\begin{array}{l}\text { Unsatisfactory } \\
\text { for } \\
\text { measurement } \\
41.5\end{array}$ \\
\hline
\end{tabular}

Table I Clinical, biochemical, and histochemical data in patients with hypothyroid myopathy.

${ }^{1}$ All the patients showed the clinical features of hypothyroidism.

- Proximal muscle weakness

- Normal muscle strength

TSH = thyroid stimulating hormone; $T_{3}$ uptake $=$ tri-iodothyronine resin uptake test; $T_{4}=$ serum thyroxine: $C_{P K}=$ creatine phosphokinase

\section{Results}

The percentages of type I and type II fibres before and during treatment are shown in fig 1 together with the values for controls. Statistical analysis of fibre type frequency using the Mann-Whitney $U$ test showed a significantly lower percentage of type II fibres in the untreated hypothyroid group $(P<0.02)$. The extent of these changes was directly related to the degree of hypothyroidism, as judged clinically and biochemically, and to the serum level of CPK (table I). After treatment with L-thyroxine ov for periods from four to 24 months fibre type ratios tended towards normal (fig 1) although a significantly lower percentage of type II fibres persisted $(P<0.02)$.

The diameters of type I and type II fibres from the hypothyroid patients and controls are shown in figure 2. Patients 3, 4, and 5 show an increase in the proportion of smaller type II fibres before treatment. Significant type II fibre atrophy $(\mathrm{P}<0.01)$ was confirmed in hypothyroid females (patients 3,4

\begin{tabular}{|c|c|c|c|c|c|c|}
\hline \multirow[t]{3}{*}{$\begin{array}{l}\text { Patient } \\
\text { Number }\end{array}$} & \multicolumn{3}{|c|}{$\begin{array}{l}\text { Type I } \\
\text { Median Diameters }(\mu)\end{array}$} & \multicolumn{3}{|c|}{$\begin{array}{l}\text { Type II } \\
\text { Median Diameters }(\mu)\end{array}$} \\
\hline & \multicolumn{2}{|c|}{ Male Hypothyroid Patients } & \multirow[t]{2}{*}{ Male Controls } & \multicolumn{2}{|c|}{ Male Hypothyroid Patients } & \multirow[t]{2}{*}{ Male Controls } \\
\hline & $A$ & $B$ & & $A$ & $B$ & \\
\hline 1 & $54 \cdot 6$ & $69 \cdot 7$ & $\begin{array}{l}46.5 \\
55 \cdot 1 \\
69 \cdot 1 \\
53 \cdot 5 \\
67.6\end{array}$ & $60 \cdot 8$ & $60 \cdot 0$ & $\begin{array}{l}58 \\
53.8 \\
61.9 \\
62.9 \\
67.6\end{array}$ \\
\hline \multirow[t]{3}{*}{2} & $68 \cdot 6$ & $57 \cdot 8$ & $\begin{array}{l}53 \cdot 6 \\
60 \cdot 0\end{array}$ & 53 & $56 \cdot 5$ & $\begin{array}{l}57 \cdot 6 \\
71 \cdot 8\end{array}$ \\
\hline & \multicolumn{2}{|c|}{ Female Hypothyroid Patients } & Female Controls & \multicolumn{2}{|c|}{ Female Hypothyroid Patients } & Female Controls \\
\hline & $A$ & $B$ & & $A$ & $B$ & \\
\hline 3 & $56 \cdot 8$ & $65 \cdot 0$ & $50 \cdot 3$ & $29 \cdot 3$ & $46 \cdot 7$ & 52 \\
\hline 4 & $42 \cdot 7$ & 51.7 & $51 \cdot 7$ & $34 \cdot 7$ & $42 \cdot 1$ & $46 \cdot 4$ \\
\hline 5 & $60 \cdot 1$ & $53 \cdot 1$ & $50 \cdot 6$ & $32 \cdot 2$ & 53.6 & 59.5 \\
\hline 6 & $\begin{array}{l}\text { Unsatisfactory } \\
\text { for measurement }\end{array}$ & 44.9 & $\begin{array}{l}58 \cdot 6 \\
56 \cdot 4\end{array}$ & $\begin{array}{l}\text { Unsatisfactory } \\
\text { for measurement }\end{array}$ & 45 & $\begin{array}{l}54 \cdot 7 \\
53 \cdot 1\end{array}$ \\
\hline
\end{tabular}

Table II Median diameters of type I and type II fibres in hypothyroid male and female patients before and during treatment with L-thyroxine, together with control values

$A=$ before treatment $B=$ during treatment with L-thyroxine 

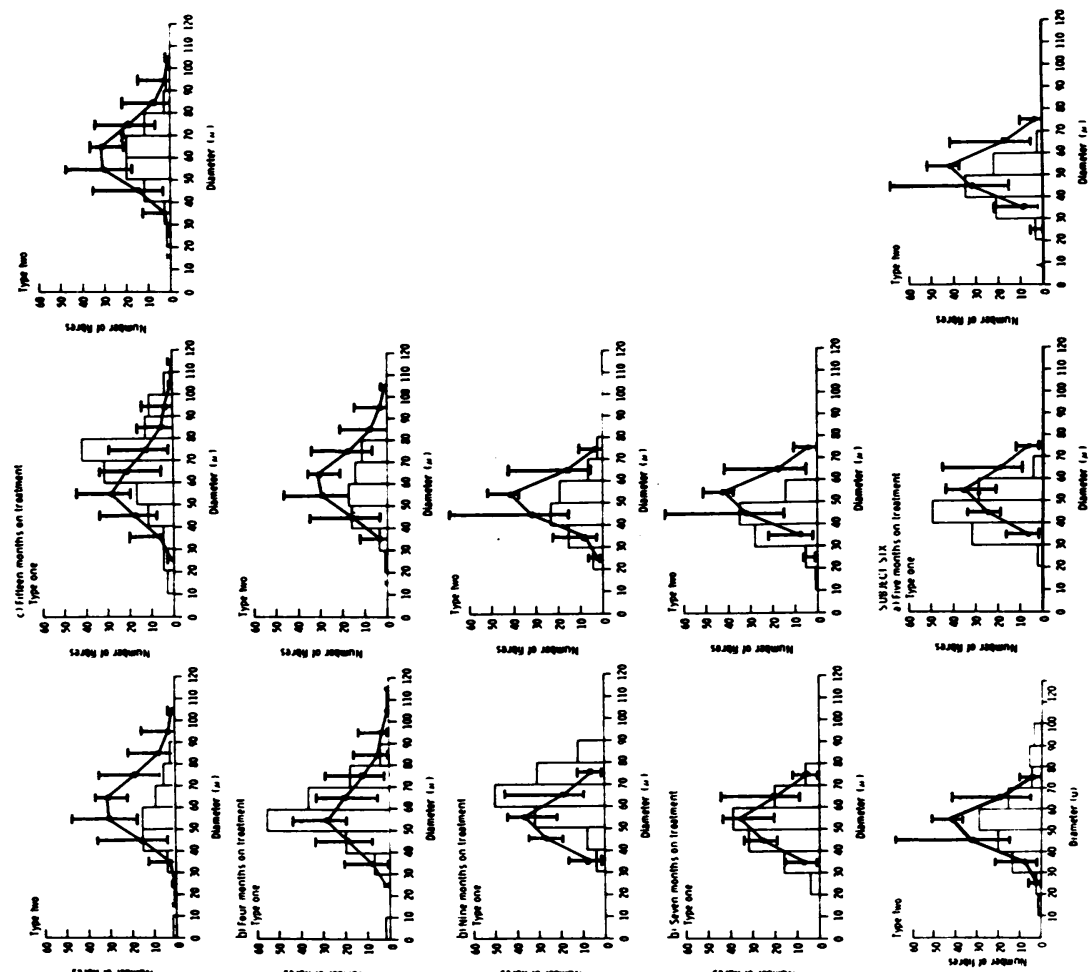

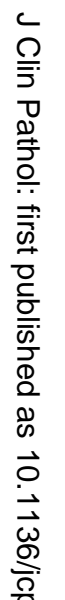
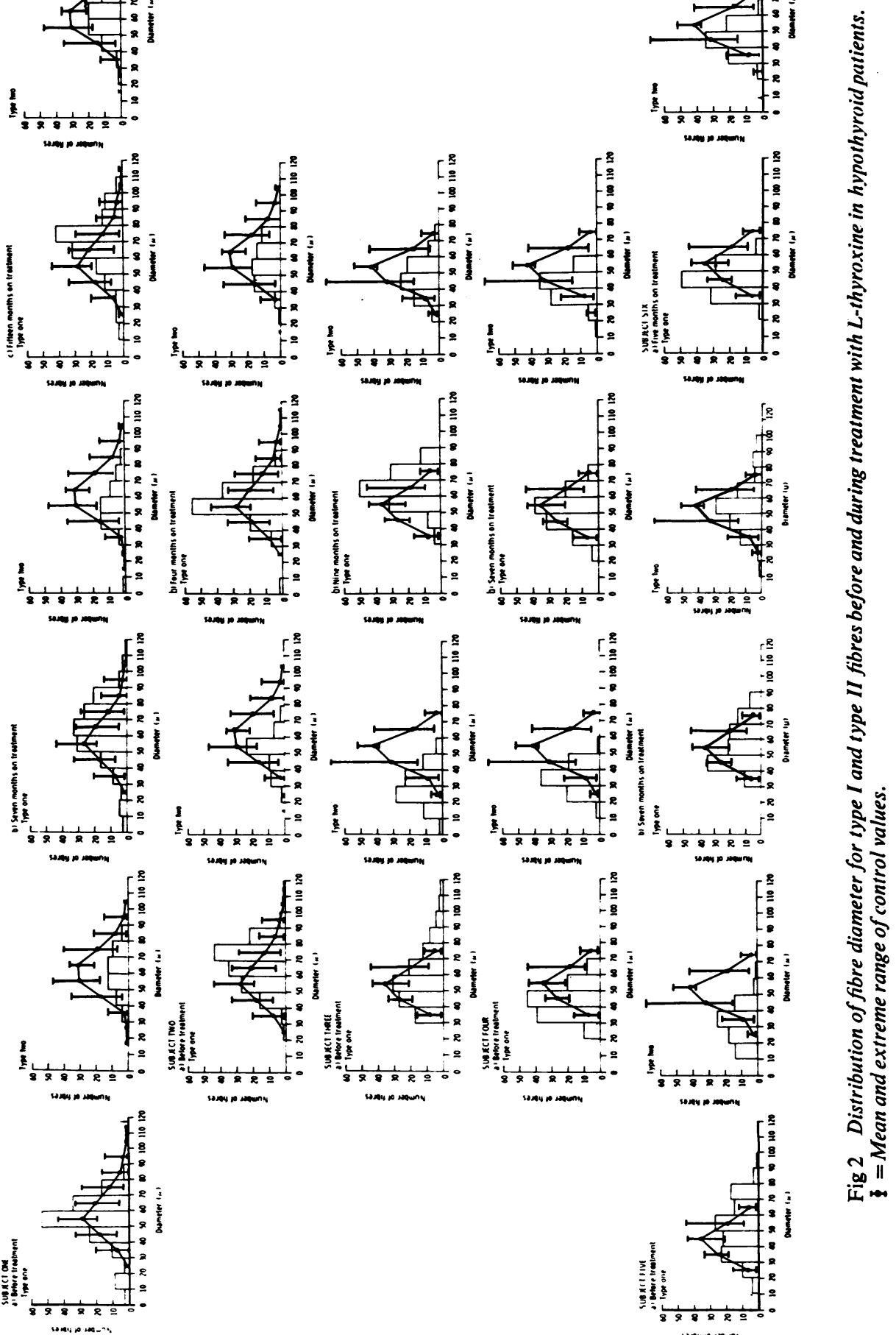
and 5) using the Mann-Whitney $U$ test applied to median fibre diameters (table II), but no significant differences from normal were demonstrated after treatment or in male type II fibres or type I fibres from either sex before or after treatment.

\section{Discussion}

Increased serum CPK levels, electromyographic changes, light and electron microscopic study indicate that hypothyroidism is associated principally with a myopathic rather than a neuropathic muscle weakness (Ramsay, 1974), but it is possible that the elevation of serum CPK is not entirely due to skeletal muscle damage since cardiac muscle is also affected (Griffiths, 1965). Light microscopic studies of muscle from hypothyroid patients have generally shown areas of focal necrosis, some variability in the size of muscle fibres, and evidence of regeneration, but serial quantitative studies to determine the effect of treatment have not previously been described.

The observed alteration in the ratio of type $I$ to type II fibres could be explained by a selective atrophy and loss of type II fibres, increase of type I fibres, conversion of type II fibres to type I fibres or any combination of these three factors. Significant type II atrophy (smaller fibre diameter) was found only in the less severely hypothyroid patients (patients 3, 4, and 5) whereas type II fibre loss (fewer fibres) while present in all patients, was most marked in those severely myopathic (patients 1 and 2 ). This suggests progression from selective atrophy to loss of type II fibres with increasing severity of hypothyroidism and myopathy. It is known that type II fibres predominate in normal proximal muscle (Johnson, Polgar, Weightman, and Appleton, 1973); the observation of type II fibre loss proportional to the severity of hypothyroidism might therefore explain the characteristic pattern of proximal weakness in hypothyroid myopathy.

Selective atrophy of type II fibres is a common abnormality previously reported in collagen vascular disease (Engel, 1965), severe rheumatoid disease (Dubowitz and Brooke, 1973), Cushing's syndrome (Pleasure, Walsh, and Engel, 1970), Parkinson's disease (Edström, 1970a, b), and in association with pyramidal tract lesions (Brooke and Engel, 1969a, b; Edström, 1970a). It has been suggested that type II atrophy simply represents disuse of the muscle (Dubowitz and Brooke, 1973). However, prolonged immobilization of injured knee joints leads to a selective atrophy of type I fibres in quadriceps (Edström, 19701,). It is unlikely, therefore, that disuse atrophy is a satisfactory explanation of the type II fibre atrophy and loss found in hypo- thyroid patients. Other possible aetiological mechanisms have been considered to explain the muscle involvement in hypothyroidism: mucopolysaccharide deposition in muscle (Nickel et al, 1961; Aström, Kugelberg, and Müller, 1961), myofibre damage induced by hypothermia (Lambert, Underdahl, Beckett, and Mederos, 1951) and autoimmune myositis (Fessel and Raas, 1968). No evidence for these processes was found in this material and an explanation of the selective fibre type atrophy and loss should be sought in the metabolic defect.

Histochemical methods show that type II muscle fibres are richer in myophosphorylase than type I which conversely are richer in oxidative enzymes associated with mitochondrial respiration (Dubowitz and Pearse, 1960). Type II fibres are thought, therefore, to derive their supply of adenosine triphosphate from glycogenolysis, glycolysis, and oxidative respiration, whereas type I fibres depend more heavily on mitochondrial respiration. Thyroxine is known to facilitate the stimulation of adenylcyclase by adrenaline leading to activation of phosphorylase and glycogen breakdown. Lack of thyroxine may thus lead to impairment of glycogen utilization in muscle, resulting in muscle fibre damage with a selective atrophy and loss of type II fibres, which owing to their greater dependence on glycogenolysis, and glycolysis for energy supplies, would be most affected.

We are indebted to Miss S. Chinn from the Division of Computing and Statistics, Clinical Research Centre, Northwick Park Hospital, for the statistical analysis.

\section{References}

Aström, K. E., Kugelberg, E., and Müller, R. (1961). Hypo thyroid myopathy. Arch. Neurol., 5, 472-482.

Brooke, M. H. and Engel, W. K. (1969a). The histographic analysis of human muscle biopsies with regard to fiber types. I. Adult male and female. Neurology (Minneap.) 19, 221-223.

Brooke, M. H. and Engel, W. K. (1969b). The histographic analysis of human muscle biopsies with regard to fiber types. 2. Diseases of the upper and lower motor neuron. Neurology (Minneap.), 19, 378-393.

Dubowitz, V. and Brooke, M. H. (1973). Muscle Biopsy: A Modern Approach. W. B. Saunders, London.

Dubowitz, V. and Pearse, A. G. E. (1960). Reciprocal relationship of phosphorylase and oxidative enzymes in skeletal muscle. Nature (Lond.), 185, 701-702.

Edström, L. (1970a). Selective changes in the sizes of red and white muscle fibres in upper motor lesions and Parkinsonism. J. neurol. Sci., 11, 537-550.

Edström, L. (1970b). Selective atrophy of red muscle fibres in the quadriceps in long-standing knee-joint dysfunction: injuries to the anterior cruciate ligament. J. neurol. Sci., 11, 551-558. 
Edwards, R. H. T. (1971). Percutaneous needle-biopsy of skeletal muscle in diagnosis and research. Lancet, 2 , 593-596.

Engel, W. K. (1965). Muscle biopsy. Clin. Orthop., 39, 80-105.

Fessel, W. J. (1968). Myopathy of hypothyroidism. Ann. rheum. Dis., 27, 590-596.

Fessel, W. J. and Raas, M. C. (1968). Autoimmunity in the pathogenesis of muscle disease. Neurology (Minneap.), 18, 1137-1139.

Graig, F. A. and Smith, J. C. (1965). Serum creatine phosphokinase activity in altered thyroid states. J. clin. Endocr., 25, 723-731.

Griffiths, P. D. (1965). Serum enzymes in diseases of the thyroid gland. J. clin. Path., 18, 660-663.

Hayashi, M. and Freiman, D. G. (1966). An improved method of fixation for formalin-sensitive enzymes with special reference to myosin adenosine triphosphatase. J. Histochem. Cytochem., 14, 577-581.

Johnson, M. A., Polgar, J., Weightman, D., and Appleton, D. (1973). Data on the distribution of fibre types in thirty-six human muscles: an autopsy study. J. Neurol. Sci., 18, 111-129.

Lambert, E. H., Underdahl, L. O., Beckett, S., and Mederos, L. O. (1951). A study of the ankle jerk in myxedema. J. clin. Endocr., 11, 1186-1205.

Nickel, S. N., Frame, B., Bebin, J., Tourtellotte, W. W., Parker, J. A., and Hughes, B. R. (1961). Myxedema neuropathy and myopathy: a clinical and pathological study. Neurology (Minneap.), 11, 125-137.

Ozker, R. R., Schumacher, O. P., and Nelson, P. A. (1960). Electromyographic findings in adults with myxedema: report of 16 cases. Arch. Phys. Med., 41, 299-307.

Padykula, H. A. and Herman, E. (1955). The specificity of the histochemical method for adenosine triphosphatase. J. Histochem. Cytochem., 3, 170-183.

Pleasure, D. E., Walsh, G. O., and Engel, W. K. (1970). Atrophy of skeletal muscle in patients with Cushing's syndrome. Arch. Neurol., 22, 118-125.

Ramsay, I. (1974). Muscular abnormalities of hypothyroidism In Thyroid Disease and Muscle Dysfunction, Ch. 4, pp. 126-171. Heinemann, London. 